medRxiv preprint doi: https://doi.org/10.1101/2020.10.11.20210005; this version posted October $14,2020$. The copyright holder for this preprint (which was not certified by peer review) is the author/funder, who has granted medRxiv a license to display the preprint in All rights reserved. No reuse allowed without permission.

\title{
CORRELATION BETWEEN SARS-COV-2 ANTIBODY SCREENING \\ BY IMMUNOASSAY AND NEUTRALIZING ANTIBODY TESTING
}

\begin{abstract}
Alfredo Mendrone-Junior ${ }^{1,6}$, Carla Luana Dinardo ${ }^{1,6}$, Suzete Cleuza Ferreira ${ }^{1}$, Anna Nishia ${ }^{1}$, Nanci Alves Salles ${ }^{1}$, Cesar de Almeida Neto ${ }^{1}$, Debora Toshei Hamasaki ${ }^{1}$, Tila Facincani ${ }^{1}$, Lucas Bassolli de Oliveira Alves ${ }^{2}$, Rafael Rahal Guaragna Machado ${ }^{4}$, Danielle Bastos Araujo ${ }^{4}$, Edison Luiz Durigon ${ }^{4,5}$, Vanderson Rocha ${ }^{1,2,6}$, Ester Cerdeira Sabino $^{3}$
\end{abstract}

1. Fundação Pro Sangue Hemocentro de São Paulo, São Paulo, Brazil

2. Serviço de Hematologia, Hemoterapia e Terapia Celular - HCFMUSP, São Paulo, Brazil

3. Instituto de Medicina Tropical, FMUSP, São Paulo, Brazil

4. Departamento de Microbiologia, Instituto de Ciências Biomédicas, Universidade de São Paulo, Brazil

5. Scientific Platform Pasteur USP, São Paulo, Brazil

6. Laboratory of Medical Investigation in Pathogenesis and Directed Therapy in Onco-Immuno-Hematology (LIM-31) HCFMUSP, University of Sao Paulo Medical School, Sao Paulo, Brazil 
medRxiv preprint doi: https://doi.org/10.1101/2020.10.11.20210005; this version posted October 14, 2020. The copyright holder for this preprint (which was not certified by peer review) is the author/funder, who has granted medRxiv a license to display the preprint in All rights reserved. No reuse allowed without permission.

\section{Abstract}

Background: Passive antibody therapy with convalescent plasma (CP) represents a promising alternative for the treatment of SARS-CoV-2 infection. The efficacy of CP therapy has been associated with high titers of neutralizing antibodies (nAbs) in the plasma of recovered patients, but the assays for quantifying nAbs are not widely available. Our goal was to develop a strategy to predict high titers of $n A b s$ based on the results of anti-SARS-CoV-2 immunoassays and the clinical characteristics of the CP potential donors.

Methods: Two hundred and fourteen CP donors were enrolled and tested for the presence of anti-SARS-CoV-2 antibodies using two commercial immunoassays (IA): Anti-SARS-CoV-2 ELISA IgG EUROIMMUN and Anti-SARS-CoV-2 Chemiluminescence IgG Abbott. In parallel, quantification of neutralizing antibodies (nAbs) was performed using the Cytopathic effect-based virus neutralization test (CPE-VNT). Three criteria for identifying donors with high titers of nAbs ( $\geq 1: 160)$ were tested: - Criterion1: Curve ROC Method; - Criterion 2: Conditional decision tree considering only the results from the IA and -Criterion 3: Conditional decision tree including both the IA results and the clinical variables.

Results: The performance of Abbott and EUROIMMUN immunoassays was similar referring to both $\mathrm{S} / \mathrm{CO}$ and predictive value for identifying nAbs titers $\geq$ 1:160. Regarding the three studied criteria for identifying CP donors with high nAbs titers ( $\geq 1: 160): 1$ ) Criterion 1 showed $76.1 \%$ accuracy when the S/CO cutoff of 4.65 was used, 2) Criterion 2 presented $76.1 \%$ accuracy if the S/CO $\geq 4.57$ was applied and 3) Criterion 3 had $71.6 \%$ accuracy if either $\mathrm{S} / \mathrm{CO} \geq 4.57$ or $\mathrm{S} / \mathrm{CO}$ between 2.68 and 4.57 and the last COVID-19-related symptoms occurred less than 19 days from donor recruiting were used.

Conclusion: The results of SARS-CoV-2 immunoassays (S/CO) can be used to predict high nAbs titers of potential CP donors. This study has proposed three different criteria for identifying donors with $\geq 1: 160 \mathrm{nAbs}$ titer based on either solely S/CO results or S/CO together with clinical variables, all with high efficacy and accuracy. 
medRxiv preprint doi: https://doi.org/10.1101/2020.10.11.20210005; this version posted October $14,2020$. The copyright holder for this preprint (which was not certified by peer review) is the author/funder, who has granted medRxiv a license to display the preprint in All rights reserved. No reuse allowed without permission.

Keywords: COVID-19, SARS-CoV-2, neutralizing antibodies, immunoassays, convalescent plasma.

\section{Introduction}

The outbreak of severe acute respiratory syndrome coronavirus 2 (SARS-CoV2) represents an unprecedent challenge for the population, health workers and government all over the world, becoming a global public health emergency with growing impact on the global economy. On 11th March 2020, the World Health Organization (WHO) declared SARS-CoV-2 a pandemic. As of August 23 $3^{\text {th }}, 2020$, SARS-CoV-2 infection reached about 23 million confirmed cases worldwide in more than 213 countries and caused more than 800,000 deaths (https://covid19.who.int). To date, no specific treatment was proved to be effective for SARS-CoV-2 infection, beside supportive care.

Passive antibody therapy with convalescent plasma (CP), a classic adaptive immunotherapy, has been applied to the prevention and treatment of many infectious diseases over many decades, from A/H1N1 Spanish Flu in 1917-1918 to SARS in 2012. ${ }^{1}$ The efficacy of passive antibody therapy has been associated with the concentration of neutralizing antibodies (nAbs) in plasma of recovered patients. ${ }^{2} \mathrm{CP}$ from patients who have recovered from viral infection can be used to improve clinical conditions and survival rate of patients with acute viral infections, including SARS-CoV-2, without severe adverse effects. Preliminary data showed a reduction of viral load, shorter hospital stay and lower mortality in patients infected by SARS-CoV-2 treated with CP in comparison to those who were not. ${ }^{3,4-8}$

Possible mechanisms related to the efficacy of CP therapy in SARS-CoV-2 include the passive transfusion of neutralizing antibodies and an immunomodulatory effect via amelioration of severe inflammatory response. . $^{9,10}$ Patients infected with SARS-CoV-2 usually develop a primary immune response by days $10-14$, which is followed by virus clearance..$^{11}$ Therefore, theoretically, it should be more effective to administer the CP at the early stage of disease. A recent matched study suggested that non-intubated patients may benefit more than those requiring mechanical ventilation. ${ }^{12}$ However, other treatments might 
medRxiv preprint doi: https://doi.org/10.1101/2020.10.11.20210005; this version posted October $14,2020$. The copyright holder for this preprint (which was not certified by peer review) is the author/funder, who has granted medRxiv a license to display the preprint in All rights reserved. No reuse allowed without permission.

influence the relationship between $\mathrm{CP}$ and antibody level, including antiviral drugs, steroids, and intravenous immunoglobulin.

We are conducting a prospective randomized trial to evaluate the efficacy of CP for patients with moderate to severe SARS-CoV-2 disease. Convalescent donors have been recruited from the community. Pre-requisite for plasma donation include age (>18 years old); no previous pregnancy; time elapsed from the last day of symptoms (> 14 days); laboratorial evidence of prior infection by SARSCoV-2; and screening negative for infectious diseases transmissible for blood (HIV 1+2, HTLV 1+2, hepatitis B and C, syphilis and Chagas Disease). Moreover, we also have evaluated the level of neutralizing antibodies (nAbs) and the absence of RNAemia in a blood samples before plasma collection. As nAbs play important roles on virus clearance and have been considered as a key immune product for treatment against viral diseases, in concordance with Food and Drug Administration (FDA), we stablished that CP unit for transfusion should contain nAbs with minimum titer of $\geq 1: 160$ (https://www.fda.gov/media/136798/download).

However, neutralization assays for SARS-CoV-2 are limited in availability and throughput, requiring biosafety level 3 facilities and skilled labor. Since such assay is often unavailable, one alternative is to perform the test later in a stored sample, or to perform another test to detect the presence of anti-SARS-CoV-2 antibody prior to issuing the plasma unit for transfusion.

The correlation between immunoassays antibodies titers and neutralizing antibodies has not been thoroughly investigated and the knowledge of this association can help to make better therapeutic decisions.

The aim of this study is to evaluate the performance of criteria based on the results of anti-SARS-CoV-2 immunoassays for the prediction of high nAbs titers in CP donors.

\section{Methods}

\section{Cohort recruiting}


medRxiv preprint doi: https://doi.org/10.1101/2020.10.11.20210005; this version posted October $14,2020$. The copyright holder for this preprint (which was not certified by peer review) is the author/funder, who has granted medRxiv a license to display the preprint in All rights reserved. No reuse allowed without permission.

Two hundred and sixty-three convalescent individuals were evaluated in April 2020 for plasma convalescent donation by apheresis. The SARS-Cov-2 infection was previously confirmed by Real Time Reverse TranscriptionPolymerase Chain Reaction (RT-PCR) of material collected from the upper respiratory tract (nasopharynx or oropharynx). All candidates provided written informed consent and tested negative for SARS-CoV-2 by RT-PCR. Blood samples were collected from all participants for performing the SARS-CoV-2 IgG immunoassay and blood RT-PCR. Two hundred and fourteen were tested for neutralizing antibodies.

\section{Immunoglobulin G (IgG) immunoassays}

Two commercials immunoassays comprising the structural protein of SARS-CoV2 (S1 domain) were tested in parallel with all collected samples: Anti-SARS-CoV2 ELISA IgG EUROIMMUN (Lübeck, Germany) and Anti-SARS-CoV-2 Chemiluminescence IgG Abbott (Chicago, US). Tests were performed in accordance with the manufacturer's instructions.

\section{Quantitative reverse-transcriptase polymerase chain reaction (RT-qPCR)}

Blood samples with $\mathrm{DO} / \mathrm{CO} \geq 3$ on the $\lg$ immunoassay were subjected to SARS-CoV-2 RT-qPCR using TaqMan method. A quantitative in house real-time PCR assay amplifying the virus RdRp RNA-dependent RNA polymerase and envelope was applied to determine the copy number of SARS-CoV-2. ${ }^{13}$ The test had sensitivity of approximately 100 copies $/ \mathrm{mL}$. In all amplification reactions, positive and negative controls and an exogenous internal control were used.

\section{Cytopathic effect-based virus neutralization test (CPE-VNT)}

Two hundred and fourteen samples were tested for neutralizing antibodies (nAbs) using the cytopathic effect-based virus neutralization test (CPE-VNT). The CPEVNT was adapted from Nurtop et al., $2018^{14}$ and have been already described on Wendel et al., $2020^{15}$. Briefly, $5 \times 10^{4}$ cells $/ \mathrm{mL}$ of Vero cells (ATCC CCL-81) were seeded 24 hours before the infection in a 96-well plate. Plasma samples were, initially, inactivated for $30 \mathrm{~min}$ at $56^{\circ} \mathrm{C}$. We used 8 dilutions (two-fold) of each plasma (1:20 to 1:2560). Subsequently, plasma was mixed vol/vol with $10^{3}$ 
medRxiv preprint doi: https://doi.org/10.1101/2020.10.11.20210005; this version posted October $14,2020$. The copyright holder for this preprint (which was not certified by peer review) is the author/funder, who has granted medRxiv a license to display the preprint in All rights reserved. No reuse allowed without permission.

TCID50/mL of SARS-CoV-2/human/BRA/SP02cc/2020 strain virus (GenBanK access number: MT350282.1) $)^{16}$ and pre-incubated at $37^{\circ} \mathrm{C}$ for 1 hour to allow virus neutralization. Then, the plasma plus virus mixture was transferred onto the confluent cell monolayer and incubated for 3 days at $37^{\circ} \mathrm{C}$, under $5 \% \mathrm{CO}_{2}$. Virus neutralization titer referred to $\mathrm{VNT}_{100}$ is described as the highest dilution of serum that neutralized virus growth (absence of cytopathic effect). In each assay, a strong, assured internal positive control serum (RT-qPCR positive + $\left.\mathrm{PRNT}_{90}>640\right)^{17}$ was used, as a negative pre-outbreak serum sample. All the procedures related to CPE-VNT were performed in a biosafety level 3 laboratory, in accordance with $\mathrm{WHO}$ recommendations ${ }^{18}$.

\section{Statistical analysis}

A descriptive analysis was carried out using frequencies, central tendency and position measures. Mann-Whitney and Kruskall-Wallis non-parametric tests were used to compare nAbs values in different groups and Bonferroni post-hoc method was applied to adjust results for multiple comparisons. The variables age and days since last symptom were tested according to groups from tertiles of the distribution values.

Simple linear regression models were used to assess the relationship between ELISA S/CO values and the concentration of nAbs titers. The predictive value of immunoassays tests (Abbott and Euroimmun) for the identification of nAbs $\geq 160$ was assessed using ROC curve graphs. ${ }^{19}$ Then, the sensitivity, specificity, predictive values and accuracy of four cut-off points obtained by different methods were calculated: a) The Youden's index method which maximizes the sum between Sensitivity and Specificity; b) The 'Maximum Efficiency' method which is based on the maximization of the frequency of cases correctly classified (true positives or true negatives); c) The 'PROC01' method which is the point on the ROC curve closest to the point to the point $(0,1)$ or upper left corner of the graph; d) a last method which established a fixed value for sensitivity $(=90 \%)$ and sought to maximize specificity.[ref 19/20]

To validate the proposed donation criteria, the total sample studied was divided into two parts (development sample and validation sample) according to the study 
medRxiv preprint doi: https://doi.org/10.1101/2020.10.11.20210005; this version posted October $14,2020$. The copyright holder for this

preprint (which was not certified by peer review) is the author/funder, who has granted medRxiv a license to display the preprint in

All rights reserved. No reuse allowed without permission.

enrollment date. For this analysis, the initial sample of 214 donors was divided into tertiles according to the date of the enrollment. The first two thirds of sample (development sample) were used to develop the criteria, while the last third of the sample (validation sample) was used to assess the performance of the proposed criteria. Three different criteria have been developed; (1-) the first criterion established a S/CO cut-off point of 4.65 based on the Youden's index method; (2-) the second criterion was established based on the results of a simple conditional decision tree model using only the result of the ELISA test as an explanatory variable and (3-) the third criterion was established based on the results of a multivariate conditional decision tree model using the ELISA test result and the following variables: age, sex, need for hospitalization for treatment of SARS-CoV-2, and the time elapsed since the end of symptoms. All analyzes were performed in the R environment using RStudio software. ${ }^{19,20}$

\section{Results}

\section{Studied population of donors}

There were 263 potential CP donors evaluated, of whom 49 were excluded from the analysis either because nAbs titers were lacking $(n=35)$ or because the evaluation was performed less than 10 days after the symptom resolution $(n=14)$ (Figure1).

Table1 shows the descriptive data of the analyzed sample. Most donors were male $(57.9 \%)$ and young (median age was 35 years/lQR=15). The two most common clinical comorbidities were systemic arterial hypertension $(8.7 \%)$ and pulmonary disease $(6.5 \%)$.

\section{Correlation between nAbs titers and clinical / demographics factors}

The titers of $n A b s$ of the studied sample varied widely Approximately 1 in each 5 donors $(19.1 \%$ ) had nAbs titers $<1: 80$ (Figure2). Titers were significantly higher among: 1) men (difference of median=160 nAbs, $p<0.001$ ), 2) individuals in the upper tertile ofage (difference of median to lower tertile $=160 \mathrm{nAbs}, \mathrm{p}=0.003$ ) and 
medRxiv preprint doi: https://doi.org/10.1101/2020.10.11.20210005; this version posted October $14,2020$. The copyright holder for this preprint (which was not certified by peer review) is the author/funder, who has granted medRxiv a license to display the preprint in All rights reserved. No reuse allowed without permission.

3) individuals who needed hospitalization to treat SARS-CoV-2 (difference of median=1,120 nAbs, $p<0.001)$. Donors with a shorter time between the end of symptoms and the enrollment had slightly higher nAbs titer, but without statistical significance $(p=0.067)$ (Figure3).

\section{Performance of the evaluated immunoassays}

The distribution of the $\mathrm{S} / \mathrm{CO}$ values obtained from the two evaluated immunoassays (Abbott and Euroimmun) is shown in Figure4, letter A. A very

similar distribution was noted. Median values of S/CO were 4.65 (IQR 2.70-7.18) and 5.61 (IQR 2.72-9.10) for Abbott and Euroimmun, respectively.

There was a positive correlation between $\mathrm{S} / \mathrm{CO}$ and nAbs titers for both Abbott $\left(R^{2}=0.617 ; p<0,001\right)$ and Euroimmun $\left(R^{2}=0.526 ; p<0,001\right)$ assays (Figure4, letter $B)$. Also, the predictive value to identify nAbs titers $\geq 160$ was similar between the two assays, with AUC value of 0.878 (IQR 0.83-0.92) and 0.885 (IQR 0.84-0.93) for Abbott and Euroimmun, respectively $(p=0.803)$ (Figure4, letter $C)$. Since both assays presented similar performance, next results were analyzed using Abbott kit.

Table2 shows the accuracy measurements of four different cut-offs for the identification of nAbs values $\geq 160$. The cut-off points obtained by the Youden and Maximum Efficiency methods showed the highest values of accuracy and area under curve (AUC). The PROC01 and Sensitivity $=90 \%$ methods showed slightly lower AUC values despite the high sensitivity values found.

The next step was to determine the accuracy of different S/CO cut-offs for predicting nAbs titers $\geq 160$ (Table2). The cut-off points obtained by the Youden and Maximum Efficiency methods presented the highest values of accuracy and area under curve (AUC). The PROC01 and Sensitivity methods showed slightly lower AUC values despite the high sensitivity values found.

\section{Validation of the S/CO cut-off as criteria for selecting donors with high nAbs titers}


medRxiv preprint doi: https://doi.org/10.1101/2020.10.11.20210005; this version posted October 14, 2020. The copyright holder for this preprint (which was not certified by peer review) is the author/funder, who has granted medRxiv a license to display the preprint in All rights reserved. No reuse allowed without permission.

For validating the S/CO optimal cut-off, the initial sample of 214 donors was divided into tertiles from the date of the interview. The first two thirds (development sample) were used to develop the criteria, while the last third of the sample (validation sample) was used to validate the proposed criteria.

The clinical and laboratorial characteristics of the development sample $(n=147)$ and validation sample $(n=67)$ are presented in Table3. The two samples had very similar characteristics regarding age, gender, nAbs titers, S/CO values and need for hospitalization. Nevertheless, the time since last symptoms and recruitment was significantly longer in the validation sample (median 24, IQR 1829) days, when compared to the development sample (median 19, IQR 17-24).

Three different criteria for the selection of donors were tested based on the results obtained in the development sample. Criterion 1 calculated the best cut-off point for the identification of nAbs titers $\geq 160$ according to the Youden's index method (S/CO> 4.65). Criteria 2 and 3 were elaborated from conditional decision trees. Figure5 illustrates the result from conditional tree of criteria 2, which proposed a criterion for donation considering solely on the result of the immunoassay. In this model, nine out of ten potential donors (95.9\%) with S/CO values $>4.57$ had nAbs titles $\geq 160$. On the other hand, the rate of potential donors not eligible for donation with $\mathrm{nAbs}$ titers $\geq 80$ was high in the group with positive ELISA 42/55 $(76.4 \%)$.

The third criterion revealed that all donors with $\mathrm{S} / \mathrm{CO}$ values $>6.11$ had nAbs titers $\geq 160$ (sensitivity $=100 \%$ ) and one third of the donors $(11 / 33)$ with the time since the end of symptoms $>19$ days had nAbs titers $<80$. All donors with S/CO values $>2.68$ who reported more recent symptom resolution (between 10 and 19 days before recruitment) showed $n A b s$ values $\geq 80$. Thus, the third donation criterion tested in the validation sample provides for the donation based on S/CO values > 4.57 and S/CO values between 2.68 and 4.57 as long as symptom resolution has been recent (between 10 and 19 days before recruitment) (Figure6). 
medRxiv preprint doi: https://doi.org/10.1101/2020.10.11.20210005; this version posted October $14,2020$. The copyright holder for this preprint (which was not certified by peer review) is the author/funder, who has granted medRxiv a license to display the preprint in All rights reserved. No reuse allowed without permission.

The performance analysis of the three criteria tested in the validation sample showed similar results. In general, better results were observed for the prediction of nAbs titers $\geq 1: 80$ when compared to the results of the prediction of nAbs $\geq$ 160. Criterion 3 demonstrated a reduction in the rate of potential donors discarded (40.3\%) and, above all, in the false negative rate. The overall accuracy of the prediction of nAbs $\geq 1: 80$ increased from $71.6 \%$ to $76.1 \%$ (Table4). On the other hand, the criterion 3 test in the validation sample also markedly increased the false positive rate for predicting nAbs $\geq 1: 160$ (Table5).

\section{Discussion}

Passive antibody therapy with convalescent plasma (CP), an adaptive immunotherapy, is an alternative for patients with SARS-CoV-2 until more definitive treatments as monoclonal antibody, antiviral drugs or vaccine are available. This treatment was used more than a century ago during the $\mathrm{A} / \mathrm{H} 1 \mathrm{~N} 1$ Spanish Flu outbreak, in 1917-1918, and more recently for AIDS, MERS, SARS and EBOLA viral epidemies. ${ }^{1,21-23}$ It consists in bringing to a patient suffering a severe and even lethal infection, immunoglobulins and possibly other immune regulatory factors obtained from plasma of immunized donors. The action mechanism of plasma therapy is not fully stablished and probably go beyond of neutralizing antibodies administration. Especially in severe acute respiratory infections of viral etiology an effect immunomodulatory through administration of anti-inflammatory cytokines could be involved. ${ }^{9}$

Up to now, there is no well-designed prospective randomized clinical trial demonstrating the efficacy of CP against infectious disease. However, Brazilian Ministry of Health is permitting the use of $\mathrm{CP}$ as an investigational treatment for patients with moderate or severe SARS-CoV-2 infection ${ }^{24}$. It is considered an investigational treatment because clinical studies have started but have not yet been completed. The success of $\mathrm{CP}$ is related to the presence of high titers of nAbs in the donated plasma. To our knowledge, the present study was the first to correlate the results obtained from two broadly available immunoassays designed to detect anti-SARS-CoV-2 antibodies with the nAbs titers. 
medRxiv preprint doi: https://doi.org/10.1101/2020.10.11.20210005; this version posted October $14,2020$. The copyright holder for this preprint (which was not certified by peer review) is the author/funder, who has granted medRxiv a license to display the preprint in All rights reserved. No reuse allowed without permission.

Our data show good correlation between nAbs titers and $S / C O$ values obtained from two immunoassays analyzed, Abbott and Euroimmun $(p<0.001)$. These data have already been observed in other manuscripts that used an immunoassay. ${ }^{25-}$ ${ }^{28}$ However, this is the first report showing a positive correlation between nAbs tested by an ELISA and a Chemiluminescence assay. This correlation is very important since many services do not have access to measuring nAbs, and, in this scenario, an immunoassay can be used as a screening to detect the presence of antibodies anti SARS-CoV-2 in the samples of convalescent donors.

Also, we have tested three criteria for identifying convalescent plasma donors with high nAbs titers. According to Youden method, the best cut-off point for the identification of $n A b s$ titers $\geq 160$ is $\mathrm{S} / \mathrm{CO}>4.65$. When a conditional decision tree model based solely on the result of the immunoassay was evaluated, $95.9 \%$ of potential donors with $\mathrm{S} / \mathrm{CO}$ values $>4.57$ had $\mathrm{nAbs}$ titers $\geq 160$. Finally, the conditional decision tree model based not only on the results of the immunoassay but also on the time of disappearance of the symptoms revealed that all donors with $S / C O$ values $>6.11$ had nAbs titers $\geq 160$ (sensitivity $=100 \%$ ) and all donors with $\mathrm{S} / \mathrm{CO}$ values $>2.68$ who reported more recent symptom resolution (between 10 and 19 days before recruitment) showed nAbs titers $\geq 80$.

Our results confirm that S/CO values can be used to identify donors of CP with high probability to have therapeutically nAbs titers. These findings support an algorithm of screening in which donors with S/CO values above 4.57 or with cutoff higher than 2.68 but with time of symptoms resolution under 19 days can be selected for $\mathrm{CP}$ donation with no need to perform nAbs titration. The nAbs analysis should, then, be restricted to the remaining donors with positive immunoassay results.

Finally, this study has also demonstrated the wide variability of nAbs titers among individuals recovered from COVID-19 infection. The titers were higher among patients of male sex, older age and requiring hospitalization for COVID-19 care. This data reinforces previous information available in literature. ${ }^{29}$

\section{Conclusion}


We evaluated the performance of Abbott and Euroimmun immunoassays for convalescent patient's IgG screening and the correlation between S/CO values with nAbs titers obtained by CPE-VNT. Our results show that S/CO cut-off value 4.57 can be applied to identify CP units with high nAbs titers. These findings support a CCP screening algorithm in which immunoassay for IgG testing could be first performed as a qualification testing and, in the presence of $S / C O>4.57$, CP units would be selected for transfusion. CP units with S/CO between 1.1 and 4.57 should be further tested using CPE-VNT to titrate nAbs and be issued for transfusion based on this result.

\section{Conflicts of Interest}

The authors declare no conflicts of interest.

\section{Acknowledgments}

Funding was granted by Fundação de Amparo à Pesquisa do Estado de São Paulo (FAPESP), projects no 2017/24769-2 (RRGM), 2016/20045-7 (ELD), 2020/06409-1 (ELD) and by Coordenação de Aperfeiçoamento de Pessoal de Nível Superior (CAPES), project no 88887.131387/2016-00 (DBA). 
medRxiv preprint doi: https://doi.org/10.1101/2020.10.11.20210005; this version posted October $14,2020$. The copyright holder for this preprint (which was not certified by peer review) is the author/funder, who has granted medRxiv a license to display the preprint in perpetuity.

All rights reserved. No reuse allowed without permission.

\section{References}

1. Garraud O, Heshmati F, Pozzetto B, Lefrere F, Girot R, Saillol A, Laperche S. Plasma therapy against infectious pathogens, as of yesterday, today and tomorrow. Transfus Clin Biol 2016;23: 39-44.

2. van Griensven J, Edwards T, de Lamballerie X, Semple MG, Gallian P, Baize S, Horby PW, Raoul H, Magassouba N, Antierens A, Lomas C, Faye O, Sall AA, Fransen K, Buyze J, Ravinetto R, Tiberghien P, Claeys Y, De Crop M, Lynen L, Bah El, Smith PG, Delamou A, De Weggheleire A, Haba N, Ebola-Tx C. Evaluation of Convalescent Plasma for Ebola Virus Disease in Guinea. N Engl J Med 2016;374: 33-42.

3. Mair-Jenkins J, Saavedra-Campos M, Baillie JK, Cleary P, Khaw FM, Lim WS, Makki S, Rooney KD, Nguyen-Van-Tam JS, Beck CR, Convalescent Plasma Study G. The effectiveness of convalescent plasma and hyperimmune immunoglobulin for the treatment of severe acute respiratory infections of viral etiology: a systematic review and exploratory meta-analysis. J Infect Dis 2015;211: 80-90.

4. Zhang B, Liu S, Tan T, Huang W, Dong Y, Chen L, Chen Q, Zhang L, Zhong Q, Zhang X, Zou $Y$, Zhang S. Treatment With Convalescent Plasma for Critically III Patients With Severe Acute Respiratory Syndrome Coronavirus 2 Infection. Chest 2020;158: e9-e13.

5. Chen L, Xiong J, Bao L, Shi Y. Convalescent plasma as a potential therapy for COVID-19. Lancet Infect Dis 2020;20: 398-400.

6. Duan K, Liu B, Li C, Zhang H, Yu T, Qu J, Zhou M, Chen L, Meng S, Hu Y, Peng C, Yuan M, Huang J, Wang Z, Yu J, Gao X, Wang D, Yu X, Li L, Zhang J, Wu X, Li B, Xu Y, Chen W, Peng $Y$, Hu Y, Lin L, Liu X, Huang S, Zhou Z, Zhang L, Wang Y, Zhang Z, Deng K, Xia Z, Gong $Q$, Zhang $W$, Zheng $X$, Liu Y, Yang H, Zhou D, Yu D, Hou J, Shi Z, Chen S, Chen Z, Zhang X, Yang X. Effectiveness of convalescent plasma therapy in severe COVID-19 patients. Proc Natl Acad Sci U S A 2020;117: 9490-6.

7. Salazar E, Perez KK, Ashraf M, Chen J, Castillo B, Christensen PA, Eubank T, Bernard DW, Eagar TN, Long SW, Subedi S, Olsen RJ, Leveque C, Schwartz MR, Dey M, Chavez-East C, Rogers J, Shehabeldin A, Joseph D, Williams G, Thomas K, Masud F, Talley C, Dlouhy KG, Lopez BV, Hampton C, Lavinder J, Gollihar JD, Maranhao AC, Ippolito GC, Saavedra MO, Cantu CC, Yerramilli P, Pruitt L, Musser JM. Treatment of Coronavirus Disease 2019 (COVID-19) Patients with Convalescent Plasma. Am J Pathol 2020;190: 1680-90.

8. Joyner M, Wright RS, Fairweather D, Senefeld J, Bruno K, Klassen S, Carter R, Klompas A, Wiggins C, Shepherd JR, Rea R, Whelan E, Clayburn A, Spiegel M, Johnson P, Lesser E, Baker S, Larson K, Ripoll Sanz J, Andersen K, Hodge D, Kunze K, Buras M, Vogt M, Herasevich V, Dennis J, Regimbal R, Bauer P, Blair J, van Buskirk C, Winters J, Stubbs J, Paneth N, Casadevall A. Early Safety Indicators of COVID-19 Convalescent Plasma in 5,000 Patients. medRxiv 2020.

9. Rojas $M$, Rodriguez $Y$, Monsalve DM, Acosta-Ampudia $Y$, Camacho B, Gallo JE, RojasVillarraga A, Ramirez-Santana C, Diaz-Coronado JC, Manrique R, Mantilla RD, Shoenfeld Y, Anaya JM. Convalescent plasma in Covid-19: Possible mechanisms of action. Autoimmun Rev 2020;19: 102554.

10. Tay MZ, Poh CM, Renia L, MacAry PA, Ng LFP. The trinity of COVID-19: immunity, inflammation and intervention. Nat Rev Immunol 2020;20: 363-74.

11. Tong PB, Lin LY, Tran TH. Coronaviruses pandemics: Can neutralizing antibodies help? Life Sci 2020;255: 117836.

12. Liu ST, Lin H-M, Baine I, Wajnberg A, Gumprecht JP, Rahman F, Rodriguez D, Tandon P, Bassily-Marcus A, Bander J. Convalescent plasma treatment of severe COVID-19: A matched control study. medRxiv 2020. 
medRxiv preprint doi: https://doi.org/10.1101/2020.10.11.20210005; this version posted October 14, 2020. The copyright holder for this preprint (which was not certified by peer review) is the author/funder, who has granted medRxiv a license to display the preprint in perpetuity.

All rights reserved. No reuse allowed without permission.

13. Corman VM, Landt O, Kaiser M, Molenkamp R, Meijer A, Chu DK, Bleicker T, Brunink S, Schneider J, Schmidt ML, Mulders DG, Haagmans BL, van der Veer B, van den Brink S, Wijsman L, Goderski G, Romette JL, Ellis J, Zambon M, Peiris M, Goossens H, Reusken C, Koopmans MP, Drosten C. Detection of 2019 novel coronavirus (2019-nCoV) by realtime RT-PCR. Euro Surveill 2020;25.

14. Nurtop E, Villarroel PMS, Pastorino B, Ninove L, Drexler JF, Roca Y, Gake B, Dubot-Peres A, Grard G, Peyrefitte C, Priet S, de Lamballerie X, Gallian P. Combination of ELISA screening and seroneutralisation tests to expedite Zika virus seroprevalence studies. Virol J 2018;15: 192.

15. Wendel, S. et al. Screening for SARS-CoV-2 antibodies in convalescent plasma (CCP) in Brazil: preliminary lessons from a voluntary convalescent donor program. Transfusion. DOI: 10.1111/trf.16065.

16. Araujo DB, Machado RRG, Amgarten DE, Malta FM, de Araujo GG, Monteiro CO, et al. SARS-CoV-2 isolation from the first reported patients in Brazil and establishment of a coordinated task network [Submitted]. Mem Inst Oswaldo Cruz E-pub: 08 Jul 2020.doi: 10.1590/0074-02760200342

17. Almeida FJ, Olmos RD, Oliveira DBL, Monteiro CO, Thomazelli LM, Durigon EL, Sáfadi MA, Palazzi MDP. Hematuria Associated With SARS-CoV-2 Infection in a Child. Pediatr Infect Dis J. 2020;3668

18. World Health Organization (WHO). Laboratory biosafety guidance related to the novel coronavirus ( 2019-nCoV ). 1-12 (2020).

19. Robin X, Turck N, Hainard A, Tiberti N, Lisacek F, Sanchez JC, Muller M. pROC: an opensource package for $\mathrm{R}$ and $\mathrm{S}+$ to analyze and compare ROC curves. BMC Bioinformatics 2011;12: 77.

20. Lopez-Raton, M., Rodriguez-Alvarez, M.X, Cadarso-Suarez, C. and Gude-Sampedro, F. (2014). OptimalCutpoints: An R Package for Selecting Optimal Cutpoints in Diagnostic Tests. Journal of Statistical Software 61(8), 1-36.

21. Morand-Joubert L, Vittecoq D, Roudot-Thoraval F, Mariotti M, Lefrere F, Heshmati F, Audat F, Lambin P, Barre-Sinoussi F, Lefrere JJ. Virological and immunological data of AIDS patients treated by passive immunotherapy (transfusions of plasma rich in HIV-1 antibodies). Vox Sang 1997;73: 149-54.

22. Wong VW, Dai D, Wu AK, Sung JJ. Treatment of severe acute respiratory syndrome with convalescent plasma. Hong Kong Med J 2003;9: 199-201.

23. Colebunders RL, Cannon RO. Large-scale convalescent blood and plasma transfusion therapy for Ebola virus disease. J Infect Dis 2015;211: 1208-10.

24. Brasil AVS. NOTA TÉCNICA № 19/2020/SEI/GSTCO/DIRE1/ANVISA, 2020.

25. Tan CW, Chia VN, Qin X, et al. SARS CoV 2 surrogate virus neutralization test based on antibody mediated blockage of ACE2 spike protein interaction. Nature Biotechnology volume 38, 1073-1078 (2020).

26. Kasopefoluwa Y. Oguntuyo,1,\# Christian S. Stevens, \# Chuan-Tien Hung,1 Satoshi lkegame, et al. Quantifying absolute neutralization titers against SARS-CoV-2 by a standardized virus neutralization assay allows for cross-cohort comparisons of COVID-19 sera. doi: 10.1101/2020.08.13.20157222.

27. Fan Wu AW, Mei Liu, Qimin Wang, Jun Chen, Shuai Xia, Yun Ling, Yuling Zhang, Jingna Xun, Lu Lu, Shibo Jiang, Hongzhou Lu, Yumei Wen, Jinghe Huang. Neutralizing antibody responses to SARS-CoV-2 in a COVID-19 recovered patient cohort and their implications. doi: 10.1101/2020.03.30.20047365

28. Larry Luchsinger, Brett Ransegnola, Daniel Jin, Frauke Muecksch, et al. Serological Analysis of New York City COVID19 Convalescent Plasma Donors. doi: 10.1101/2020.06.08.20124792 
medRxiv preprint doi: https://doi.org/10.1101/2020.10.11.20210005; this version posted October 14, 2020. The copyright holder for this preprint (which was not certified by peer review) is the author/funder, who has granted medRxiv a license to display the preprint in All rights reserved. No reuse allowed without permission.

29. Wu F, Liu M, Wang A, Lu L, Wang $Q$, Gu C, Chen J, Wu Y, Xia S, Ling Y, Zhang Y, Xun J, Zhang R, Xie Y, Jiang S, Zhu T, Lu H, Wen Y, Huang J. Evaluating the Association of Clinical Characteristics With Neutralizing Antibody Levels in Patients Who Have Recovered From Mild COVID-19 in Shanghai, China. JAMA Intern Med 2020.

Table 1. Descriptive data of the studied cohort of donors $(n=214)$.

Male, $\mathrm{n}(\%)$

Age years, median (IQR)

Hospitalization, $n(\%)$

Duration of symptoms (days), median (IQR)

Symptoms onset - Enrollment (days), median (IQR)

End of symptoms - Enrollment (days), median (IQR)

Comorbidities, $\mathrm{n}(\%)$

Hypertension

$18(8.4)$

Diabetes mellitus

Pulmonary disease

$14(6.5)$

Cardiac disease

Tobacco use
$124(57.9)$

$35(30-45)$

$15(7.0)$

$11(7-14)$

$31(27-39)$

$20(17-26)$
Tobacco use

$7(3.3)$ 
medRxiv preprint doi: https://doi.org/10.1101/2020.10.11.20210005; this version posted October 14,2020 . The copyright holder for this preprint (which was not certified by peer review) is the author/funder, who has granted medRxiv a license to display the preprint in All rights reserved. No reuse allowed without permission.

Table 2. DO/CO cut-offs values predicting nAbs titers $\geq 160$ according to four different methods

\begin{tabular}{ccccc}
\hline & \multicolumn{4}{c}{ Methods to find an optimal cut-off } \\
& Youden & Max efficiency & PROC01 & Sensitivity = 0.90 \\
\hline DO/CO cut-off & 4.65 & 3.81 & 1.05 & 2.8 \\
Below cut-off & $46.6 \%$ & $37.4 \%$ & $86.4 \%$ & $26.1 \%$ \\
False Positive & $3.7 \%$ & $9.8 \%$ & $22.4 \%$ & $15.9 \%$ \\
Accuracy & $77.5 \%$ & $80.8 \%$ & $70.5 \%$ & $79.4 \%$ \\
Sensitivity & $0.72(0.64-0.79)$ & $0.83(0.75-0.88)$ & $0.99(0.96-100)$ & $0.90(0.83-0.94)$ \\
Specificity & $0.89(0.80-0.95)$ & $0.72(0.61-0.82)$ & $0.37(0.26-0.49)$ & $0.55(0.43-0.67)$ \\
PPV & $0.92(0.86-0.95)$ & $0.84(0.76-0.90)$ & $0.74(0.63-0.99)$ & $0.78(0.69-0.87)$ \\
NPV & $0.64(0.55-0.81)$ & $0.69(0.59-0.80)$ & $0.96(0.83-0.98)$ & $0.75(0.63-0.83)$ \\
AUC & $0.80(0.75-0.85)$ & $0.79(0.73-0.85)$ & $0.59(0.54-0.64)$ & $0.75(0.68-0.81)$
\end{tabular}

PPV= Positive predictive value; NPV= Negative predictive value; $A U C=$ Area under the curve; PROC01 $=$ minimizes distance between ROC curve plot and point $(0,1)$

Table 3. Clinical and laboratorial characteristics of Development and Validation samples

\begin{tabular}{cccc}
\hline & $\begin{array}{c}\text { Development } \\
(\mathrm{n}=147)\end{array}$ & $\begin{array}{c}\text { Validation } \\
(\mathrm{n}=67)\end{array}$ & $\mathrm{P}$ \\
\hline Enrollment date & April 9- May 11 & May 13- June 1 & -- \\
Male, $\mathrm{n}(\%)$ & $91(61.9)$ & $33(49.3)$ & 0.112 \\
Age, median (IQR) & $35(30-43)$ & $37(31-46)$ & 0.308 \\
Hospitalization, $\mathrm{n}(\%)$ & $9(6.1)$ & $6(9.0)$ & 0.564 \\
End of symptoms-enrollment days, median (IQR) & $19(17-24)$ & $24(18-29)$ & $<0.001$ \\
SARS-CoV-2 nAbs titer, median (IQR) & $160(80-640)$ & $160(80-640)$ & 0.618 \\
SARS-CoV-2 nAbs titers $\geq 160, \mathrm{n}(\%)$ & $97(66.0)$ & $41(61.2)$ & 0.599
\end{tabular}


medRxiv preprint doi: https://doi.org/10.1101/2020.10.11.20210005; this version posted October 14,2020 . The copyright holder for this preprint (which was not certified by peer review) is the author/funder, who has granted medRxiv a license to display the preprint in All rights reserved. No reuse allowed without permission.

Elisa Abbott positive test, $\mathrm{n}(\%)$

$123(86.6)$

$57(85.1)$

0.931

Elisa Abbott DO:CO, median (IQR)

$4.57(2.72-7.17)$

$5.17(2.72-7.25)$

0.881

$I Q R=$ Intervalo interquartil

Table4. Validation metrics of three criteria to predict $n A b s$ titers $\geq 1: 80$ through Immunassay S/CO value

\begin{tabular}{|c|c|c|c|}
\hline & Criterion 1 & Criterion 2 & Criterion 3 \\
\hline DO/CO cut-off & 4.65 & 4.57 & $\begin{array}{c}4.57 \text { or }(2.68+ \\
\text { TSLS })\end{array}$ \\
\hline Below cut-off & $32(47.8 \%)$ & $32(47.8 \%)$ & $27(40.3 \%)$ \\
\hline $\begin{array}{l}\text { False positive } \\
\text { fraction }\end{array}$ & $0(---)$ & $0(---)$ & $1(1.5 \%)$ \\
\hline $\begin{array}{c}\text { False negative } \\
\text { fraction }\end{array}$ & $19(28.4 \%)$ & $19(28.4 \%)$ & $15(22.4 \%)$ \\
\hline AUC & $0.82(0.76-0.88)$ & $0.82(0.76-0.89)$ & $0.82(0.72-0.92)$ \\
\hline Global accuracy & $71.6 \%$ & $71.6 \%$ & $76.1 \%$ \\
\hline
\end{tabular}

AUC= Area under the curve; TSLS = Time since last symptom

Table 5. Validation metrics of three criteria to predict $n A b s$ titers $\geq 1: 160$ through Immunassay S/CO value. $(n=67)$

\begin{tabular}{cccc}
\hline & Criterion 1 & Criterion 2 & Criterion 3 \\
\hline DO/CO cut-off & 4.65 & 4.57 & 4.57 or (2.68 + \\
TSLS) \\
Below cut-off & $32(47.8 \%)$ & $32(47.8 \%)$ & $27(40.3 \%)$ \\
$\begin{array}{c}\text { False positive } \\
\text { fraction }\end{array}$ & $5(7.5 \%)$ & $5(7.5 \%)$ & $9(13.4 \%)$ \\
\end{tabular}


medRxiv preprint doi: https://doi.org/10.1101/2020.10.11.20210005; this version posted October 14, 2020. The copyright holder for this preprint (which was not certified by peer review) is the author/funder, who has granted medRxiv a license to display the preprint in

perpetuity.
All rights reserved. No reuse allowed without permission.

False negative

fraction

$11(16.4 \%) \quad 11(16.4 \%)$

$10(14.9 \%)$

AUC

$0.77(0.66-0.87)$

$0.77(0.66-0.87)$

$0.70(0.59-0.82)$

Global accuracy

$76.1 \%$

$76.1 \%$

$71.6 \%$

AUC= Area under the curve; TSLS = Time since last symptom

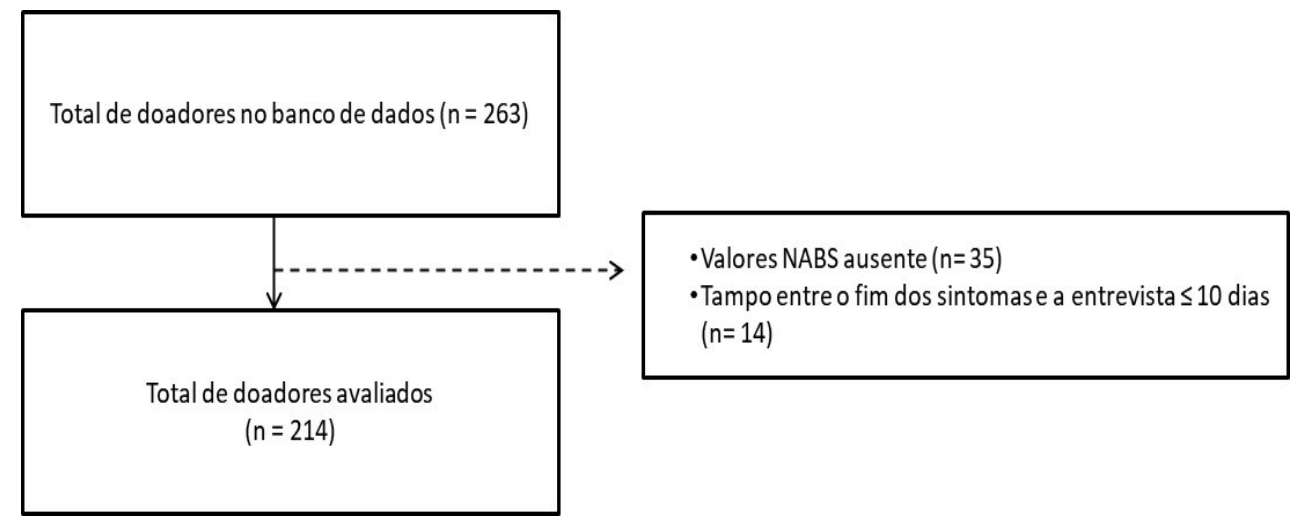

Figure1. Inclusion of the donors of convalescent plasma for the study.

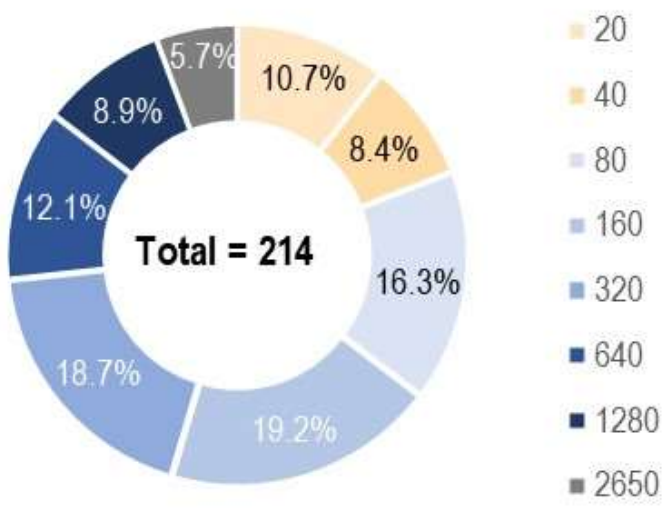

Figure2. Distribution of nAbs titers identified in the studied population of donors. 
medRxiv preprint doi: https://doi.org/10.1101/2020.10.11.20210005; this version posted October 14, 2020. The copyright holder for this preprint (which was not certified by peer review) is the author/funder, who has granted medRxiv a license to display the preprint in

All rights reserved. No reuse allowed without permission.

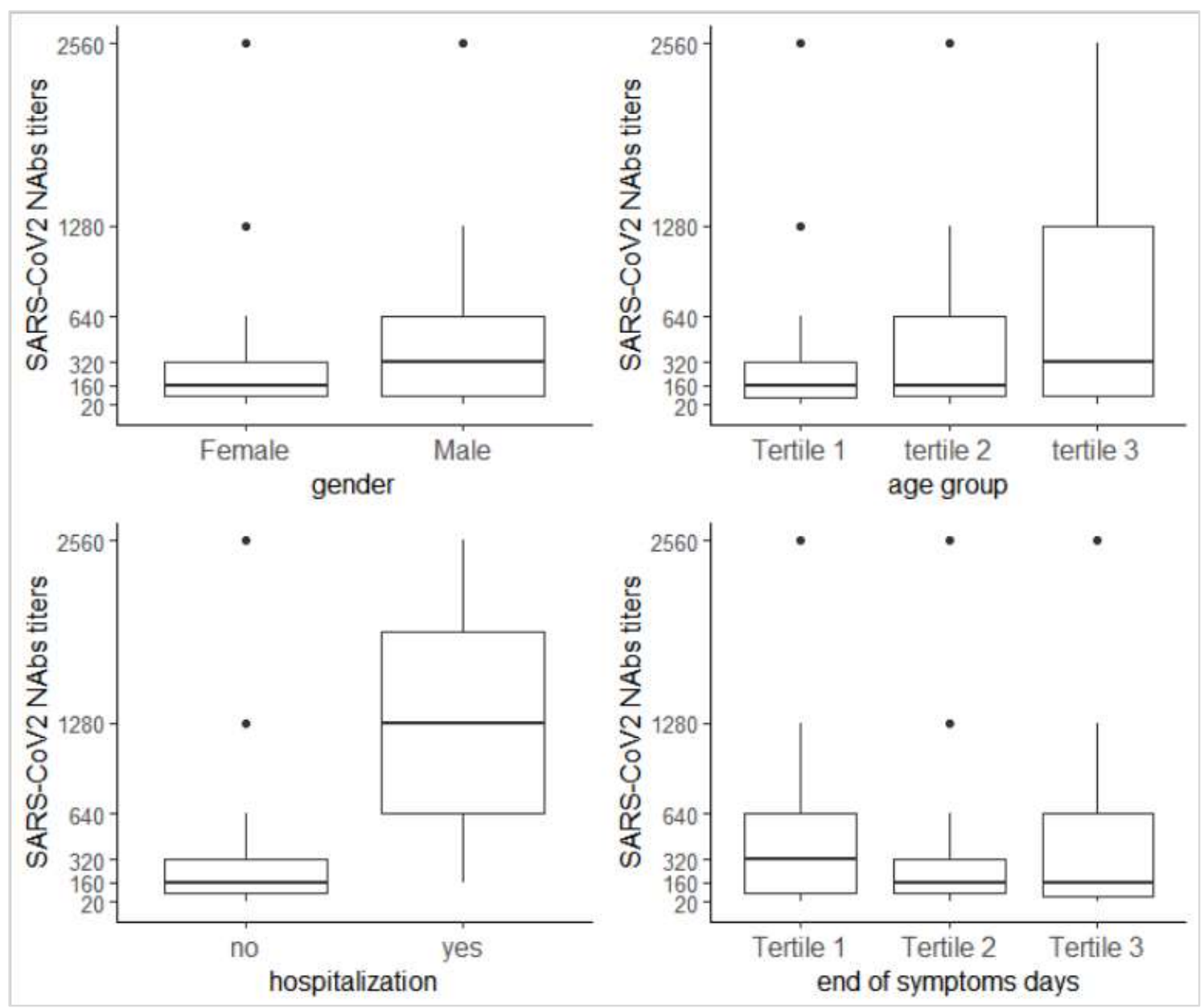

Figure3. Variation of nAbs titers according to different clinical variables: gender, age, hospitalization and time for the end of symptoms. 
A

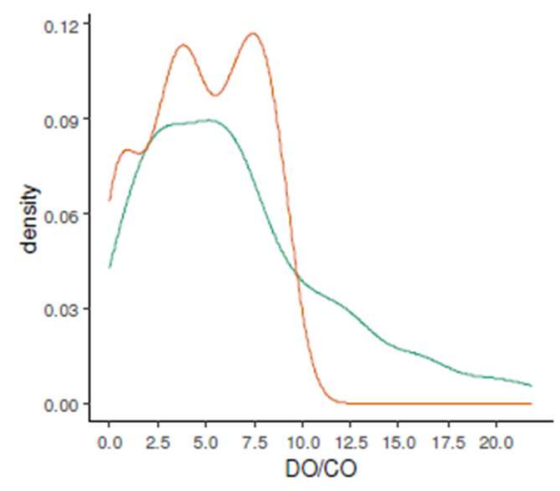

B

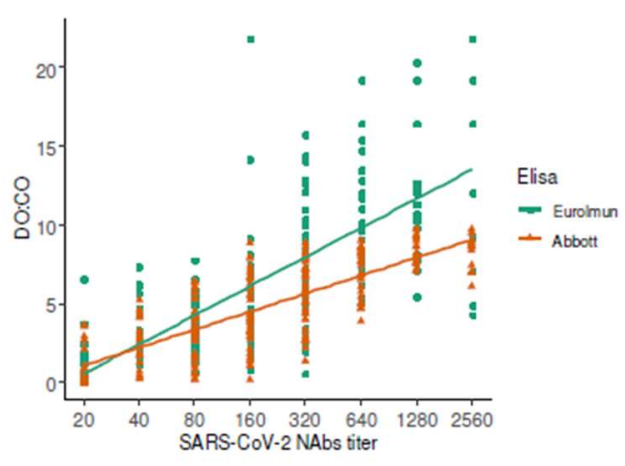

C

Eurolmun
Abbott

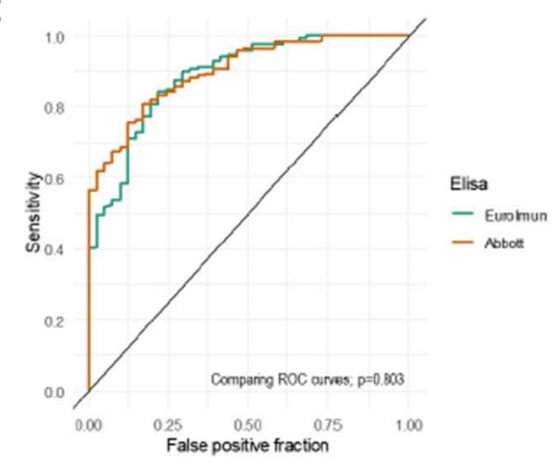

Figure4. Comparison of the performance of the two studied immunoassay tests (Euroimmun and Abbott). A. Distribution density of S/CO values obtained from two immunoassays tests $(n=214)$; B. Correlation of $n A b s$ titers and $S / C O$ values obtained from the two Immunoassays methods; C. ROC curves for identifying nAbs titers $\geq 1: 160$. 


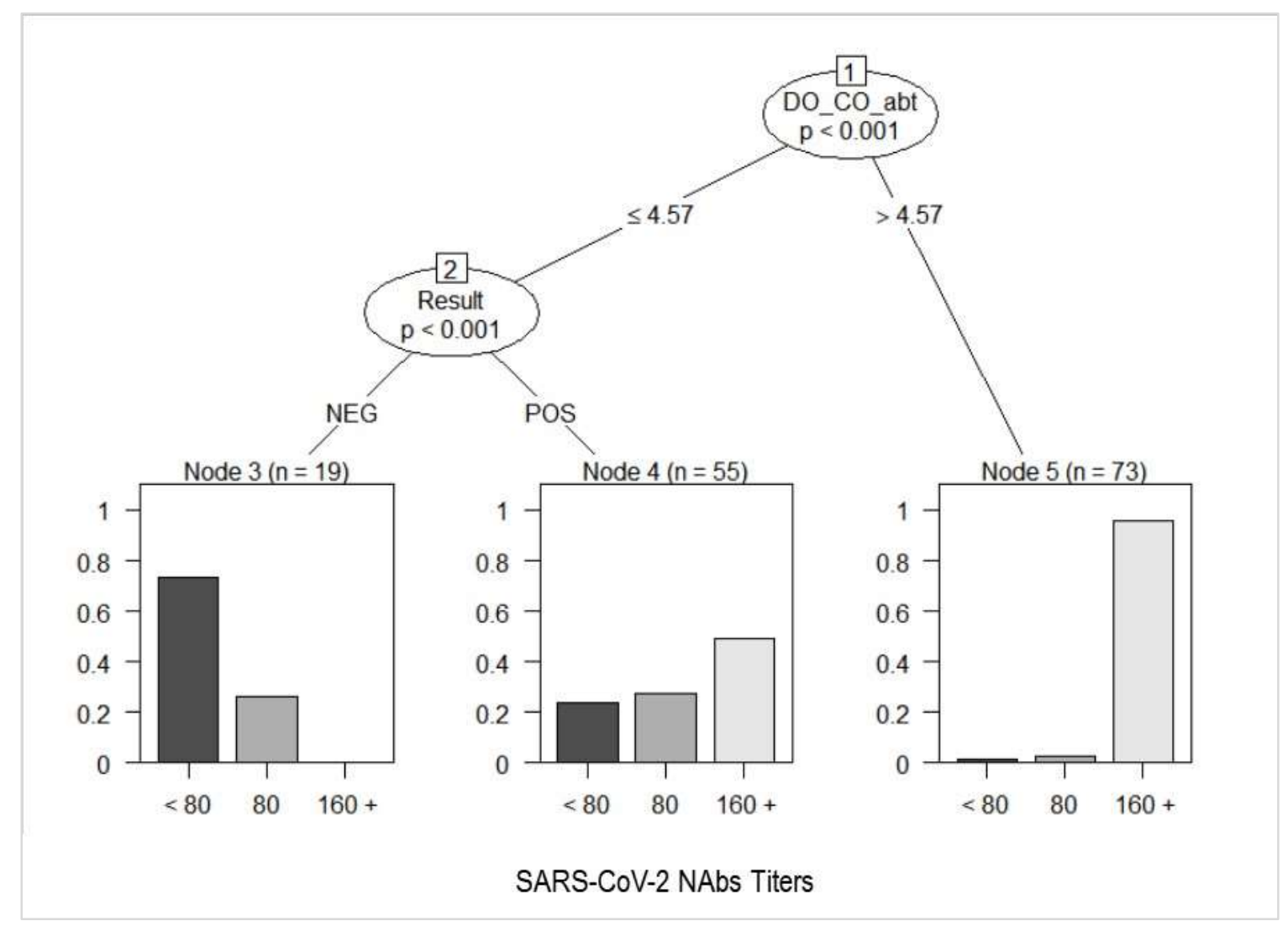

Figure5. Conditional decision tree of criterion 1 for the prediction of high nAbs titers according to Immunoassay result only.

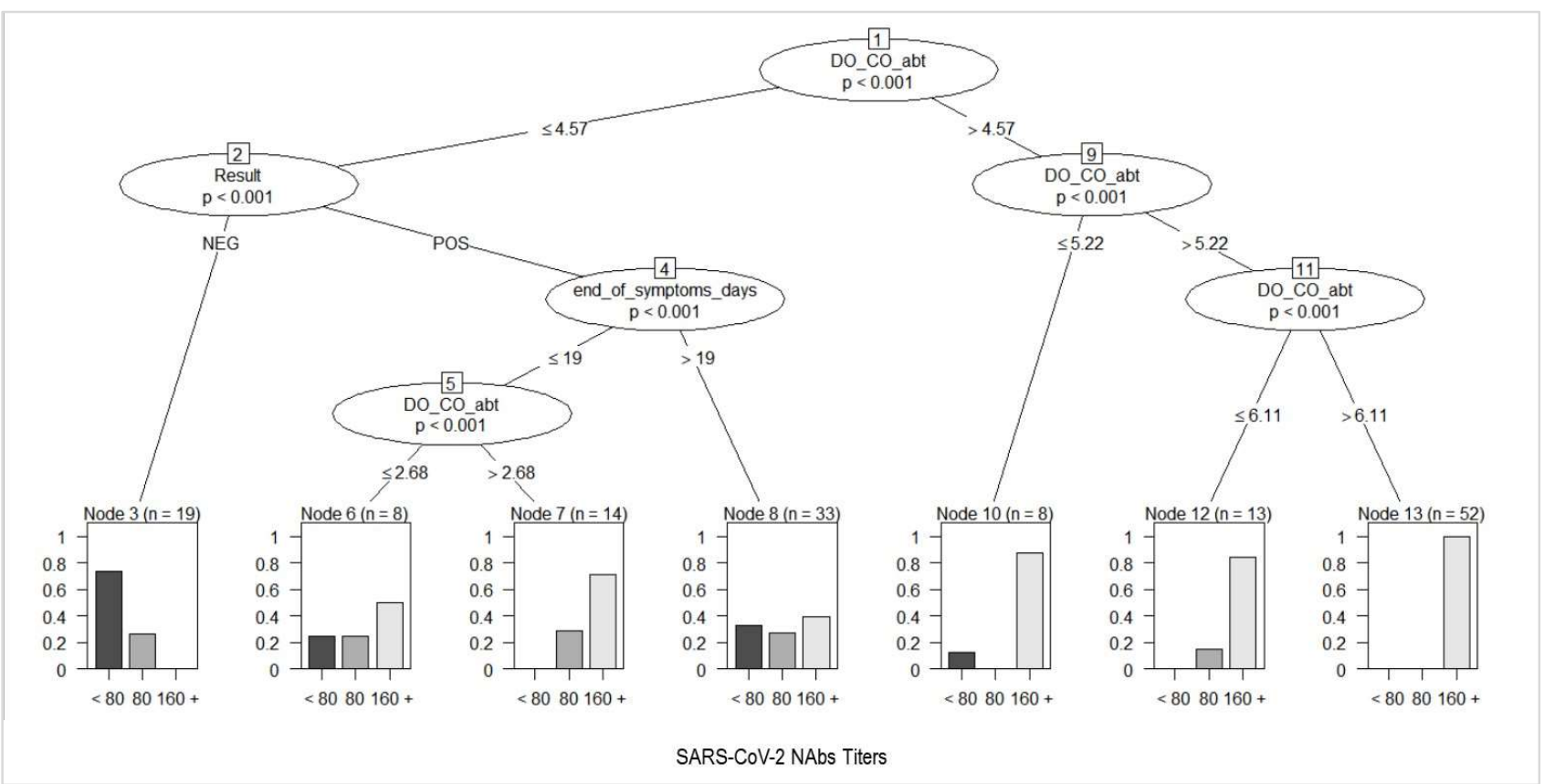

Figure6. Conditional decision tree of criterion 2 for the prediction of high nAbs titers according to Immunoassay result and the time (days) since last symptoms. 